\title{
Natural and constructed littoral zones as nutrient traps in eutrophicated shallow lakes
}

\author{
Susan Sollie $\cdot$ Hugo Coops $\cdot$ Jos T. A. Verhoeven
}

Received: 16 May 2007 / Revised: 6 January 2008/ Accepted: 20 February 2008/Published online: 8 March 2008

(C) The Author(s) 2008

\begin{abstract}
It is generally known that the water quality of shallow lakes can be influenced significantly by marginal wetlands. In order to study the efficacy of constructed littoral wetlands in the IJsselmeer area (The Netherlands) for water quality improvement, a field survey was carried out in 2003. Vegetation, soil, pore water and surface water characteristics were measured in spring and summer in two types of littoral zones: natural and constructed for 8-16 years. The study showed that constructed wetlands perform well and are suitable to enlarge the vegetated littoral zone in the IJsselmeer area. In both natural and constructed sites vegetation biomass varied between $2,200 \mathrm{~g} \mathrm{~m}^{-2}$ for helophyte vegetation and $1,300 \mathrm{~g} \mathrm{~m}^{-2}$ for low herbaceous vegetation. Nutrient concentrations in the pore water of constructed sites tended to be higher than in natural sites. $\mathrm{PO}_{4}^{3-}$ and $\mathrm{NH}_{4}^{+}$concentrations in pore water were much lower when vegetation was present, probably as a result of plant uptake. The $\mathrm{N}$ and $\mathrm{P}$ accumulation rate in the soil of constructed wetlands was $20 \mathrm{~g} \mathrm{~N}$
\end{abstract}

Handling editor: S. Declerck

S. Sollie $(\bowtie) \cdot$ J. T. A. Verhoeven

Landscape Ecology, Institute of Environmental Biology, Utrecht University, P.O. Box 80084, 3508 TB Utrecht,

The Netherlands

e-mail: ssollie@hotmail.com

H. Coops

RIZA, P.O. Box 17, 8200 AA Lelystad, The Netherlands $\mathrm{m}^{-2} \mathrm{y}^{-1}$ and $3 \mathrm{~g} \mathrm{P} \mathrm{m}^{-2} \mathrm{y}^{-1}$ in vegetated plots; without vegetation the rate was much lower $(8 \mathrm{~g} \mathrm{~N}$ $\mathrm{m}^{-2} \mathrm{y}^{-1}$ and $1.8 \mathrm{~g} \mathrm{P} \mathrm{m}^{-2} \mathrm{y}^{-1}$ ). We conclude that concerning their effect on water quality, constructed sites may replace natural sites, at least after 816 years. Principal component analysis showed a relationship between vegetation biomass and flooding, and nutrient concentrations in soil and pore water. Biomass was negatively correlated with extractable nutrients and positively with soil total $\mathrm{N}$ and $\mathrm{P}$ content. Flooding duration was negatively related to pore water salinity and positively to pore water nutrients. Due to their high biomass, helophyte stands retained significantly more nutrients than low pioneer vegetation and are therefore more suitable for improving water quality.

Keywords Water quality - Phragmites australis . Artificial wetland - Shallow lake ·

Water level fluctuations - Biogeochemistry

\section{Introduction}

The great majority of shallow lakes in the temperate zone have had a history of serious eutrophication as a result of high nutrient loading. Although water quality in European shallow lakes has improved considerably over the last decades, it is still far from standards of a good ecological quality (Smith, 2003). 
High amounts of nutrients enter lakes and cause eutrophication phenomena, including cyanobacterial blooms (Scheffer, 2001). The prospects for further reduction of nutrient loading are often limited, also because reductions of the external loading are often compensated by internal loading, without much change of the lake water quality (Gulati \& Van Donk, 2002; Søndergaard et al., 2003). Therefore, internal management may be required to improve the nutrient status of lakes. Various studies have indicated that the water quality of shallow lakes can be improved by the construction of marginal wetlands and a suitable water level regime (Verhoeven \& Meuleman, 1999; Coops \& Hosper, 2002; Coveney et al., 2002).

The shallow lakes of the IJsselmeer area in The Netherlands are characterized by high nutrient levels causing blooms of cyanobacteria and turbid water. The water management in these manipulated lakes accommodates recreation, navigation and the use of the surrounding polders for agriculture. This has resulted in an artificial water regime with smallamplitude water levels, which are slightly higher in summer than in winter, while the natural water regime would be characterized by high levels in winter and spring and lower levels in summer and autumn. The lack of naturally fluctuating water levels prevents the development of wide zones of emergent vegetation (Lammens, 1999). These zones could otherwise enhance water quality by acting as a nutrient sink through plant uptake (Verhoeven \& Meuleman, 1999; Coveney et al., 2002; Meuleman et al., 2002), trapping nutrients by sediment deposition (Johnston et al., 1984) and reducing sediment resuspension (James et al., 2004).

The water level regime is important for the development of shore vegetation (Coops et al., 2004). Biogeochemical processes in the littoral sediment affecting the transformation and mobility of nutrients from pore water or surface water, including nitrogen removal by nitrification-denitrification and phosphate adsorption, are influenced by water level fluctuations as well (Patrick \& Delaune, 1977; Mitsch \& Gosselink, 2000; Ann et al., 2000).

Several wetland creation projects have been carried out along the lakeshores of the IJsselmeer area and various others are in a planning stage. These projects encompass the deposition of mineral sand (very low organic matter content) to elevate ground level to a level at which helophytes may colonize or planted. About 350 ha of artificial shore wetlands have already been completed, and another 1,250 ha are planned for the next years (www.rdij.nl).

The artificial littoral sites may differ from existing natural sites in soil and vegetation characteristics even after a considerable time span. In order to test the functioning of natural and constructed littoral zones in the IJsselmeer area the following research questions were raised: (1) Are constructed littoral zones comparable to natural zones with respect to nutrient retention in soil and vegetation? (2) Which parameters are important for nutrient retention in the vegetation? and (3) What are the $\mathrm{N}$ and $\mathrm{P}$ accumulation rates in the constructed zones?

We expected higher total nutrient contents and higher organic matter content in the natural littoral zones. It was assumed that $8-16$ years after construction the artificial wetlands are still developing to an equilibrium, since mainly pioneer vegetation was present. The most important parameters influencing nutrient retention in littoral wetlands were expected to be water level (flooding) and vegetation biomass.

\section{Methods}

Site description

The IJsselmeer area is situated in the centre of the Netherlands $\left(52^{\circ} 45^{\prime} \mathrm{N}, 5^{\circ} 25^{\prime} \mathrm{E}\right)$ and consists of the large lake IJsselmeer and several smaller lakes ('Randmeren'), together covering approximately $2,000 \mathrm{~km}^{2}$. In these lakes average depths range from 1.5 to $4.5 \mathrm{~m}$. The lakes are connected to each other by open connections or via sluices (Lammens, 1999). The area has been a freshwater system since 1932 the Afsluitdijk closed the IJsselmeer area off from the sea. Due to economic and safety reasons, a substantial part of the shoreline is diked and has a steep slope. Water levels are highly managed by sluices that discharge water to the sea, resulting in a non-natural water level regime (water levels in summer $20 \mathrm{~cm}$ higher than in winter). This water level regime, together with the morphometry of the shoreline has resulted in significant reductions of littoral vegetation. 
Field procedures

Sampling sites were selected in three different parts of the IJsselmeer area: IJsselmeer, Ketelmeer and Veluwemeer. In each of these lakes, one sampling area was located at a site with littoral vegetation that had developed naturally after 1932 ('natural') and another one at a site with recently (after 1990) created zones with littoral vegetation ('constructed') (Table 1). The non-natural water level regime of these lakes during the growing season (with a raise in April, followed by a constant, high summer level and a drop in October) is shown in Fig. 1. Actual shortterm water level fluctuations at the shores occur due to wind action and by the operation of sluices superimposed on water level manipulation for constant winter and summer levels. These fluctuations are highest in the IJsselmeer and more moderate in the Veluwemeer. At each sampling area, plots of $1 \mathrm{~m}^{2}$ were selected within different vegetation types, depending on their presence at the location. Vegetation type 'Helophyte monostand' not only consisted of either Phragmites australis (Cav.) Steud, or Typha angustifolia L., or T. latifolia L. 'Helophyte association' was dominated by these helophytes, but also contained species like Schoenoplectus lacustris L., Bolboschoenus maritimus L., Agrostis stolonifera L. and Mentha aquatica L. In the vegetation type 'Bulrush association' the dominant S. lacustris and $B$. maritimus were accompanied by $P$. australis, Typha spp., Lycopus europaeus L. and M. aquatica. In the 'Low herbaceous' vegetation type, 19 species occurred in rather even distributions, among which Juncus articulatus L., J. bufonius L., Cirsium arvense L., Plantago maior L., Persicaria hydropiper L. and Salix spp L. In total 30 different plots were selected. The dotted lines in Fig. 1 represent the elevation of the plots relative to water level. Some plots were flooded or dry during the entire study period, whereas others were alternately wet or dry.

Soil, pore water and surface water were sampled in May and August 2003. Vegetation was sampled only in August, while water levels were measured throughout the growing season. Soil samples were taken by mixing three subsamples per plot from the upper $10 \mathrm{~cm}$ of the soil (total volume of $0.3 \mathrm{dm}^{3}$ ). Pore water was collected using vacuum bottles connected to semi-permeable rhizons (Eijkelkamp Agrisearch Equipment BV). In each plot three

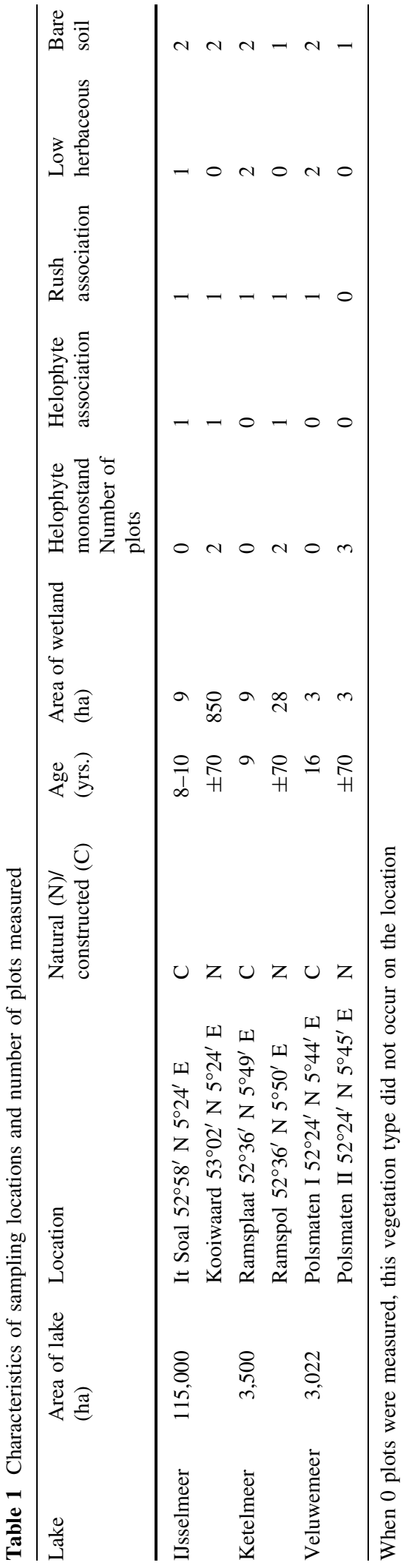


Fig. 1 Water level fluctuation in the different locations from March till August 2003. Dotted lines represent the height of the plots compared to water level $(\mathrm{NAP}=$ Amsterdam Ordnance Datum)
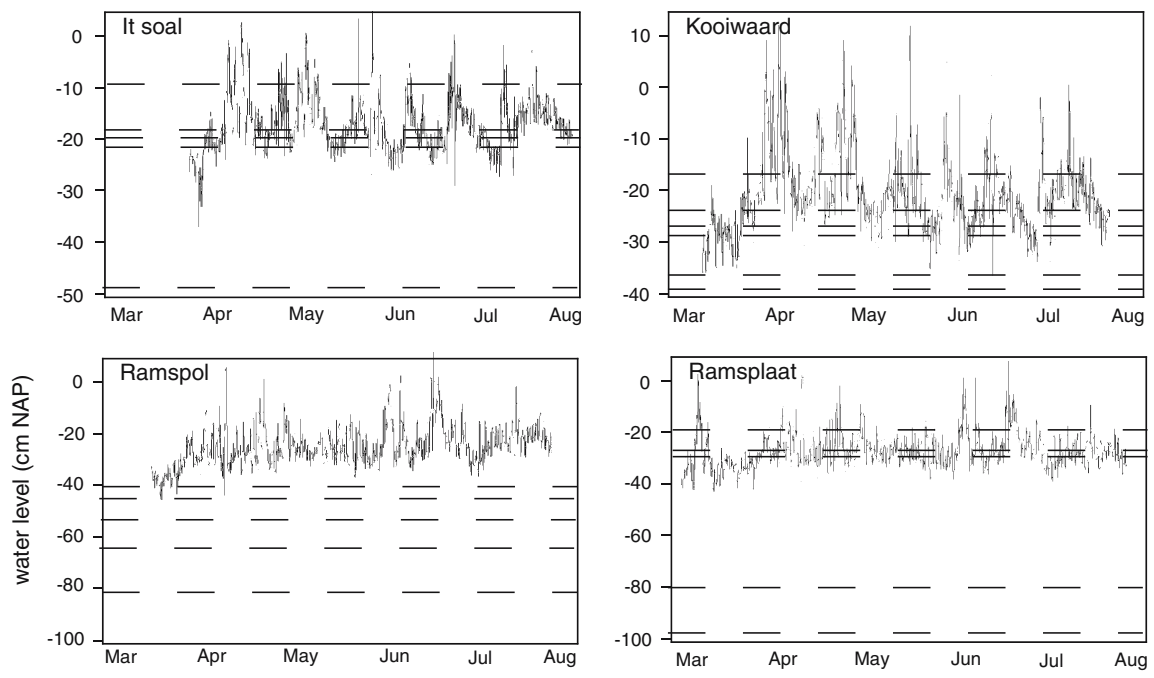

subsamples were mixed to one sample. Surface water was collected only when a plot was flooded. Soil samples were stored at $4^{\circ} \mathrm{C}$ and analysed within $24 \mathrm{~h}$. Water samples were frozen $\left(-18^{\circ} \mathrm{C}\right)$ until further analysis. In order to measure aboveground vegetation biomass, a subplot of $20 * 20 \mathrm{~cm}$ was cut at ground level, put in a plastic bag and stored at $-18^{\circ} \mathrm{C}$ until further analysis. In addition, dominant species as well as the other species present were noted. Water level was measured with half hour intervals from March to August, using divers (Van Essen Instruments). The divers measure water and air pressure and convert these data into the height of the water column. The elevation of the plots was measured with an altimeter and the total flooding duration per day and the amount of flooding events from March to August were calculated for each plot.

\section{Laboratory procedures}

Soil samples were extracted with demineralised water, $0.2 \mathrm{M} \mathrm{KCl}$ extraction $\left(\mathrm{NH}_{4}^{+}\right.$and $\left.\mathrm{NH}_{3}^{-}\right)($Houba et al., 1989) and Olsen extraction $\left(\mathrm{PO}_{4}^{3-}\right)$ (Bray \& Kurtz, 1945) within $24 \mathrm{~h}$ after collection. For demineralised water and $\mathrm{KCl}$ extractions, $100 \mathrm{ml}$ extraction solution was added to $10 \mathrm{~g}$ fresh soil and shaken for $1 \mathrm{~h}$ followed by 4 min of centrifuging at $4000 \mathrm{rpm}$. In the demineralised water extract $\mathrm{pH}$ and electric conductivity (EC) were measured. The samples were then filtered over a GF/C Whatman-filter and stored in the freezer $\left(-18^{\circ} \mathrm{C}\right)$ until further analysis. For Olsen extraction $50 \mathrm{ml}$ of $0.5 \mathrm{M}$ $\mathrm{NaHCO}_{3}$ was added to $5 \mathrm{~g}$ of fresh soil and shaken for $30 \mathrm{~min}$, centrifuged and filtered. A mixed reagent was added to the extract after which the samples were measured colorimetrically at $880 \mathrm{~nm}$ for $\mathrm{PO}_{4}^{3-}$. Sediment samples were dried $\left(70^{\circ} \mathrm{C}, 48 \mathrm{~h}\right)$ and digested with a modified Kjeldahl procedure to measure total $\mathrm{N}$ and $\mathrm{P}$ (Bremner \& Mulvaney, 1982). Five millilitre of a mixture of sulphuric acid and salicylic acid was added to $750 \mathrm{mg}$ of soil. A catalyst was added and the solution was heated for $1 \mathrm{~h}$ at $200^{\circ} \mathrm{C}$ followed by $90 \mathrm{~min}$ at $340^{\circ} \mathrm{C}$. When the samples were clear and green, they were cooled and demineralised water was added up to $75 \mathrm{ml}$. After homogenizing the samples, the supernatant was decanted and stored until further analysis on the autoanalyser. Loss on ignition was calculated by 
igniting $5 \mathrm{~g}$ of dry soil for $5 \mathrm{~h}$ at $550^{\circ} \mathrm{C}$. The accumulation rate of $\mathrm{N}$ and $\mathrm{P}$ in the soil $\left(\mathrm{g} \mathrm{m}^{-2} \mathrm{y}^{-1}\right)$ was estimated by assuming that $\mathrm{N}$ and $\mathrm{P}$ accumulation during the relatively short period since the construction of the site had occurred primarily in the top $10 \mathrm{~cm}$ of the soil. The amounts of $\mathrm{N}$ and $\mathrm{P}$ in the top $10 \mathrm{~cm}$ of soil (i.e. bulk density $*$ volume $* \mathrm{~N}$ or $\mathrm{P}$ concentration) divided by the number of years in which accumulation had taken place (8-16 years) were used as a measure of $\mathrm{N}$ and $\mathrm{P}$ accumulation. The top $10 \mathrm{~cm}$ of the soil is the most active soil zone (Yang et al., 2007) and contains the bulk of the organic matter in the constructed wetlands studied. The wetlands were constructed with a sandy bottom which initially had only low organic matter content ( $<1 \%$ on a dry weight basis), while current organic matter content of the top layer varied between 5 and $20 \%$.

$\mathrm{pH}$ and EC of both the surface and pore water samples were measured, followed by filtering over a Whatman GF/C filter (only surface water). All samples were frozen at $-18^{\circ} \mathrm{C}$ until analysis on the autoanalyser.

The plant samples collected were divided into dead and living biomass. Dry weight was determined $\left(70^{\circ} \mathrm{C}\right.$; $48 \mathrm{~h}$ ) and the weights were converted into biomass per square meter. For determination of total $\mathrm{N}$ and $\mathrm{P}$ $150 \mathrm{mg}$ of ground biomass was digested with a modified Kjeldahl procedure (Bremner \& Mulvaney, 1982).

Pore water, surface water and demineralised water extraction samples were analysed on a continuous flow autoanalyser (Skalar SA-40, Breda, The Netherlands) for $\mathrm{Fe}^{2+} / \mathrm{Fe}^{3+}, \mathrm{Al}^{3+}, \mathrm{Ca}^{2+}, \mathrm{Mg}^{2+}, \mathrm{HCO}_{3}^{-}$, $\mathrm{SO}_{4}^{2-}, \mathrm{Cl}^{-}, \mathrm{NO}_{3}^{-}, \mathrm{NH}_{4}^{+}, \mathrm{PO}_{4}^{3-}, \mathrm{Na}^{+}$and $\mathrm{K}^{+}$. For $\mathrm{KCl}$ extracts, only $\mathrm{NH}_{4}^{+}$and $\mathrm{NH}_{3}^{-}$were measured. Digested plant and soil samples were analysed for total $\mathrm{N}$ and $\mathrm{P}$.

\section{Statistics}

All statistics were performed using SPSS 12.0 (SPSS Inc., Chicago Il., USA). Significant differences between constructed and natural sites and between vegetation types were tested with One-Way ANOVA. When data did not meet the ANOVA requirements, tests for several independent samples were used (Kruskal-Wallis). In order to analyse the effects of season, location history, vegetation presence, flooding status and their interactions, four-way ANOVA's were performed. In order to test for correlations between the parameters measured, the bivariate correlations procedure (Pearson's correlation coefficient) was used. In the principal component analysis (PCA), data from spring and summer were taken together, measurements done at the same time in the same plot remaining coupled. PCA with all these variables together produced Factors with little ecological meaning. Therefore, PCA was carried out separately for the three compartments soil, pore water and surface water. The parameters in each of these compartments were reduced to three principal components (Table 3a-c). Parameters with a communality lower than 0.300 were left out of the PCA. The resulting Factors were tested for correlation with vegetation and flooding parameters using Pearson's correlation coefficient.

\section{Results}

Variation in natural and constructed littoral zones

The variables measured were tested on significant differences between the natural and constructed sites and among different vegetation types. Organic matter content (OMC), total $\mathrm{N}$ and total $\mathrm{P}$ in the soil tended to be higher in constructed sites than in natural sites, both for the vegetated and the bare plots, but the differences were not significant (Fig. 2). When comparing the vegetated plots with the unvegetated plots in the natural sites, significantly more TN and TP was present in the vegetated soil, while there was no significant difference in the constructed sites. The amounts of OM, TN and TP were not dependent on the vegetation type. As expected, in bare soil OMC, $\mathrm{TN}$ and TP was lower than in the vegetated sites.

The accumulation rate of $\mathrm{N}$ and $\mathrm{P}$ in the constructed littoral zones was higher in the vegetated plots than in the bare plots. When vegetation was present the accumulation rate was estimated at $20 \mathrm{~g}$ $\mathrm{N} \mathrm{m}^{-2} \mathrm{y}^{-1}$ in the upper $10 \mathrm{~cm}$ of the soil (assuming that the amount currently stored has been accumulated over the last $8-16$ years). Without vegetation the rate was much lower $\left(8 \mathrm{~g} \mathrm{~N} \mathrm{~m}^{-2} \mathrm{y}^{-1}\right.$ in the upper $10 \mathrm{~cm})$. For $\mathrm{P}$ the accumulation rates in the vegetated and unvegetated plots were 3 and $1.8 \mathrm{~g} \mathrm{P} \mathrm{m}^{-2} \mathrm{y}^{-1}$, respectively. In the natural plots the rate cannot be 
Fig. 2 Mean $( \pm S E)$

organic matter content (\%), total $\mathrm{N}$ and total $\mathrm{P}\left(\mathrm{mg} \mathrm{g}^{-1}\right)$ of the soil per location type (left) and vegetation type (right). $+\mathrm{V}=$ vegetated, $-\mathrm{V}=$ unvegetated.

Significant differences $(P<0.05)$ are shown within location type. n.s. $=$ not significant
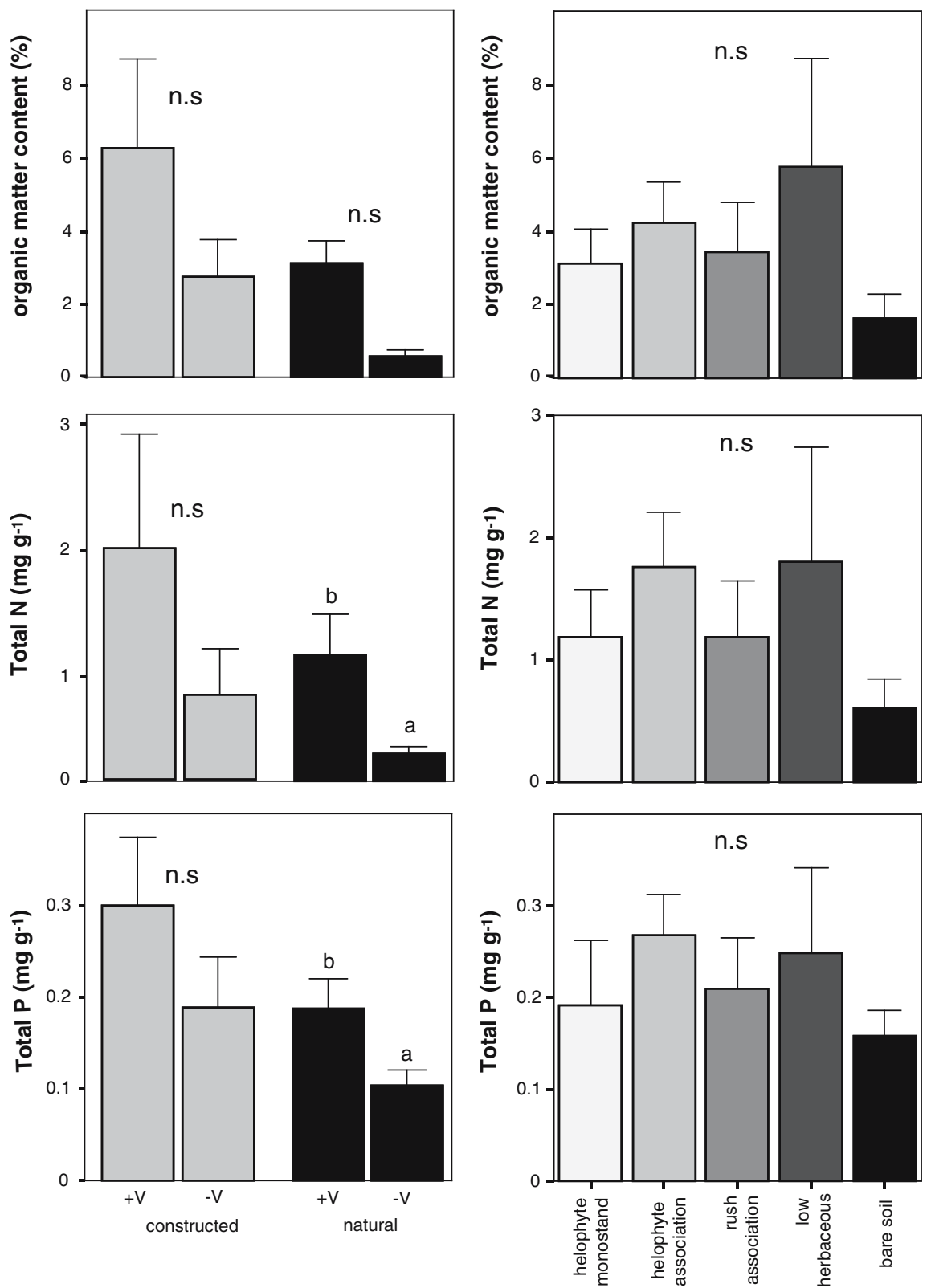

calculated because the system is assumed to be in equilibrium. In the natural vegetated plots $120 \mathrm{~g} \mathrm{~N}$ and $19 \mathrm{~g} \mathrm{P} \mathrm{m}^{-2}$ was present (top $10 \mathrm{~cm}$ ). In the unvegetated plots this was $25 \mathrm{~g} \mathrm{~N}$ and $10 \mathrm{~g} \mathrm{P} \mathrm{m}^{-2}$.

Nutrient concentrations in pore water are distinctly higher in the constructed sites than in the natural sites (Fig. 3). This is significant for ammonium $(P=0.048)$. The pore water concentrations of ammonium and phosphate were significantly higher in the unvegetated than in the vegetated sites; the difference in nitrate concentration was not significant. In surface water, there was a non-significant trend of higher nutrient concentrations in the natural sites compared to the constructed sites (Fig. 3).

Aboveground biomass and total $\mathrm{N}$ in the vegetation did not significantly differ between the constructed and natural sites but $\mathrm{P}$ content was higher in the constructed sites (Fig. 4). Biomass of the vegetation was highest in the sites dominated by helophytes. In mixed stands with helophytes as well 
Fig. 3 Mean $( \pm S E)$ ammonium, nitrate and phosphate concentrations of the pore water (grey bars) and surface water (black bars) $\left(\mathrm{mg} \mathrm{l}^{-1}\right)$ per location type (left) and vegetation type (right). Significant differences $(P<0.05)$ are shown within location type. $*$ = Significantly different for $P<0.1$, n.s. $=$ not significant
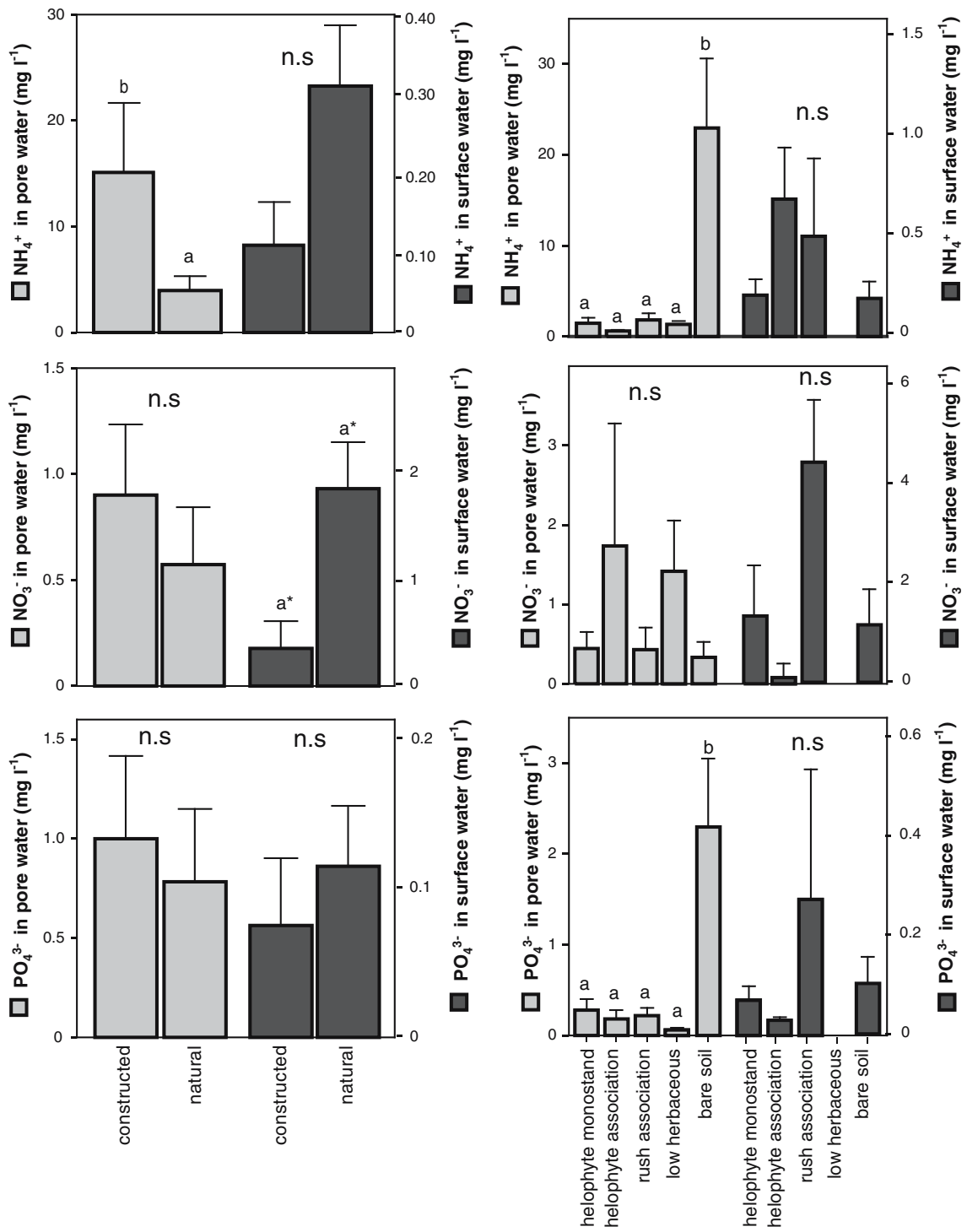

as other plant species biomass tended to be lower. $\mathrm{N}: \mathrm{P}$ ratio in all vegetation types was rather low $(\approx 10)$. The amount of nitrogen stored in the aboveground vegetation was significantly higher in monotypic helophyte stands $\left(20 \mathrm{~g} \mathrm{~N} \mathrm{~m}^{-2}\right)$ than in low herbaceous vegetation $\left(11 \mathrm{~g} \mathrm{~N} \mathrm{~m}^{-2}\right)$. A similar trend was observed for phosphorus $\left(2.0 \mathrm{~g} \mathrm{P} \mathrm{m}^{-2}\right.$ in monotypic helophyte stands and $1.5 \mathrm{~g} \mathrm{P} \mathrm{m}^{-2}$ in low herbaceous vegetation).

Four-way ANOVA's were performed to analyse the main effects of the factors (1) season, (2) location history (natural/constructed), (3) vegetation status (vegetated/unvegetated) and (4) flooding condition (flooded/dry). These factors all had two possible conditions, resulting in 1 degree of freedom each. Phosphate in pore water showed significant differences for all four factors (Table 2a) with significant interactions among the four factors. Phosphate concentration was highest in summer, in the natural sites, when vegetation was absent and when the soil was drained. In contrast, ammonium and nitrate concentrations were not significantly different for any of the four factors, except for nitrate concentration being higher in spring $(P=0.033)$ and ammonium concentration being higher in unvegetated sites $(P=0.022)$.

Extractable ammonium concentrations in the soil were significantly higher in flooded than in dry sites $(P=0.001)$, in natural sites relative to constructed 
Fig. 4 Mean $( \pm S E)$ aboveground vegetation biomass $\left(\mathrm{kg} \mathrm{m}^{-2}\right)$ and nutrient concentrations (mg $\mathrm{g}^{-1}$ ) per location type (left) and vegetation type (right). Plots with bare soil are omitted. Bars with different letters are significantly different from each other $(P<0.05)$. n.s. $=$ not significant
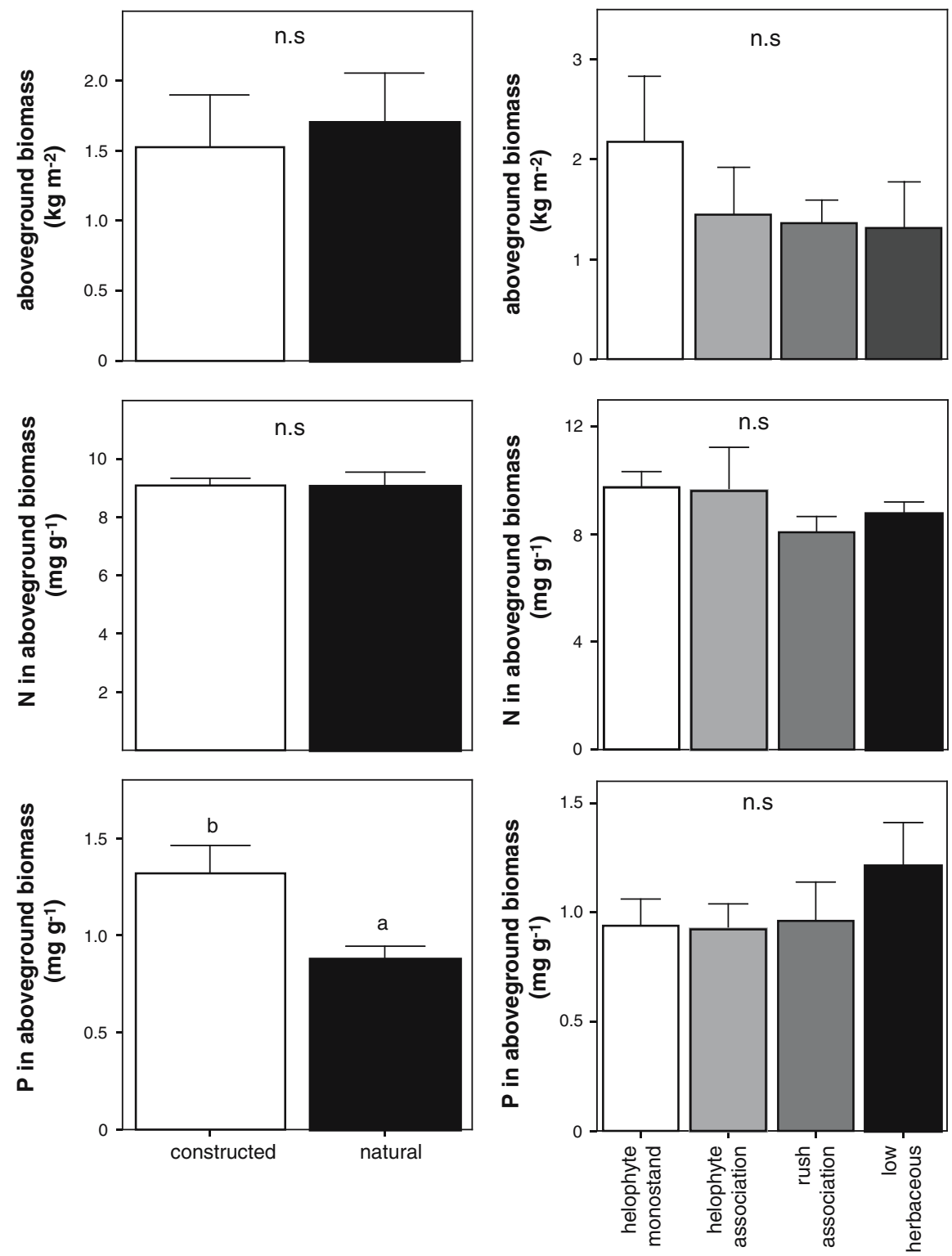

ones $(P=0.001)$, while they tended to be higher when no vegetation was present $(P=0.059)$ and higher in summer than in spring $(P=0.074)$ (Table 2b). Also, most of the two-way interactions were significant, indicating that the extractable ammonium showed complex patterns of variance. When the soil was flooded no seasonal effect was seen, but in dry conditions extractable ammonium was higher in summer than in spring. In natural sites extractable ammonium did not vary in time, whereas in the constructed sites the amount was higher in summer than in spring. Extractable ammonium was higher in constructed than in natural sites under flooded conditions, in contrast to dry conditions where no difference was found. Other nutrients in the soil as well as organic matter content were not significantly related to season, location history, vegetation status or flooding condition.

Nutrient concentrations in the surface water did not show significant differences for any of the factors (data not shown). Vegetation biomass and nutrient contents did not show significant differences between flooded and drained sites and between natural and constructed sites. 
Table 2 Four-way ANOVA; main effects and interactions of four factors for nutrients (a) in the pore water and (b) in the soil

\begin{tabular}{|c|c|c|c|}
\hline Source & Independent variable & $F$ & $P$ \\
\hline \multicolumn{4}{|l|}{ (a) } \\
\hline \multirow[t]{2}{*}{ Season } & $\mathrm{NH}_{3}^{-}\left(\mathrm{mg} \mathrm{l}^{-1}\right)$ & 4.821 & 0.033 \\
\hline & $\mathrm{PO}_{4}^{3-}\left(\mathrm{mg} \mathrm{l}^{-1}\right)$ & 16.835 & 0.000 \\
\hline Location history & $\mathrm{PO}_{4}^{3-}\left(\mathrm{mg} \mathrm{l}^{-1}\right)$ & 2.904 & 0.095 \\
\hline \multirow[t]{2}{*}{ Vegetation status } & $\mathrm{NH}_{4}^{+}\left(\mathrm{mg} \mathrm{l}^{-1}\right)$ & 5.600 & 0.022 \\
\hline & $\mathrm{PO}_{4}^{3-}\left(\mathrm{mg} \mathrm{l}^{-1}\right)$ & 29.938 & 0.000 \\
\hline Flooding condition & $\mathrm{PO}_{4}^{3-}\left(\mathrm{mg} \mathrm{l}^{-1}\right)$ & 3.637 & 0.063 \\
\hline Season $*$ loc. history & $\mathrm{PO}_{4}^{3-}\left(\mathrm{mg} \mathrm{l}^{-1}\right)$ & 3.002 & 0.090 \\
\hline Season * veg. status & $\mathrm{PO}_{4}^{3-}\left(\mathrm{mg} \mathrm{l}^{-1}\right)$ & 5.329 & 0.026 \\
\hline Loc. history $*$ veg. status & $\mathrm{PO}_{4}^{3-}\left(\mathrm{mg} \mathrm{l}^{-1}\right)$ & 24.766 & 0.000 \\
\hline \multirow[t]{2}{*}{ Loc. history $*$ flood. cond. } & $\mathrm{NH}_{4}^{+}\left(\mathrm{mg} \mathrm{l}^{-1}\right)$ & 6.639 & 0.013 \\
\hline & $\mathrm{PO}_{4}^{3-}\left(\mathrm{mg} \mathrm{l}^{-1}\right)$ & 28.323 & 0.000 \\
\hline $\begin{array}{l}\text { Veg. status * flood. cond. } \\
\text { (b) }\end{array}$ & $\mathrm{PO}_{4}^{3-}\left(\mathrm{mg} \mathrm{l}^{-1}\right)$ & 30.300 & 0.000 \\
\hline Season & Extractable $\mathrm{NH}_{4}^{+}\left(\mathrm{mg} \mathrm{g}^{-1}\right)$ & 3.337 & 0.074 \\
\hline Location history & Extractable $\mathrm{NH}_{4}^{+}\left(\mathrm{mg} \mathrm{g}^{-1}\right)$ & 11.600 & 0.001 \\
\hline Vegetation status & Extractable $\mathrm{NH}_{4}^{+}\left(\mathrm{mg} \mathrm{g}^{-1}\right)$ & 3.737 & 0.059 \\
\hline Flooding condition & Extractable $\mathrm{NH}_{4}^{+}\left(\mathrm{mg} \mathrm{g}^{-1}\right)$ & 12.728 & 0.001 \\
\hline Season $*$ loc. history & Extractable $\mathrm{NH}_{4}^{+}\left(\mathrm{mg} \mathrm{g}^{-1}\right)$ & 3.880 & 0.055 \\
\hline Season $*$ flood. cond. & Extractable $\mathrm{NH}_{4}^{+}\left(\mathrm{mg} \mathrm{g}^{-1}\right)$ & 3.579 & 0.065 \\
\hline Loc. history $*$ flood. cond. & Extractable $\mathrm{NH}_{4}^{+}\left(\mathrm{mg} \mathrm{g}^{-1}\right)$ & 12.992 & 0.001 \\
\hline
\end{tabular}

Only significant variables $(P<0.05)$ and trends $(P<0.1)$ are shown

Principal component analysis

For the soil variables (Table 3a), the first Factor of the PCA explained $49 \%$ of the variance while the second and third explained $12 \%$ and $10 \%$, respectively. Factor 1 was positively correlated with the total amounts of nutrients present in the soil (e.g. organic matter content and total $\mathrm{N}, \mathrm{P}$ and $\mathrm{K}$ ), but also with soil moisture content. Factor 2 was associated with parameters related to salinity, i.e. $\mathrm{Na}^{+}, \mathrm{Cl}^{-}, \mathrm{EC}$ and $\mathrm{HCO}_{3}^{-}$. The last Factor was related to extractable ammonium and phosphate. The soil pore water variables (Table $3 \mathrm{~b}$ ) were reduced into three Factors explaining $33 \%, 16 \%$ and $13 \%$ of the variance, respectively. Parameters indicating salinity (e.g. $\mathrm{Na}^{+}$, $\mathrm{Cl}^{-}$and EC) were clustered in Factor 1. Factor 2 was positively correlated with concentrations of oxidized $\mathrm{N}$ and $\mathrm{S}$, which can be interpreted as an indication of the redox potential in the soil pore water. Ammonium and phosphate concentrations in pore water correlated with Factor 3. For the surface water compartment (Table 3c), both the first and the second Factor explained more than $25 \%$ of the variance. Again, salinity parameters were prominently related to the first Factor. Factor 2 correlated to ammonium and phosphate, but also to bicarbonate and negatively to $\mathrm{pH}$. Factor 3 correlated positively with sulphate and negatively with iron concentrations.

The factors of the three compartments pore water, surface water and soil did show significant correlations (Table 4). Factor 2 in the soil (indicating salinity) correlated highly with the salinity Factors in both pore and surface water $(P=0.001$ and $P<0.001$, respectively). These last two factors also correlated significantly $(P<0.001)$ among each other. There was a positive correlation between extractable nutrients (Factor 3 of soil) and nutrient concentrations in the pore water $(P<0.001)$.

There were several significant correlations between vegetation, flooding duration and flooding frequency with some of the PCA Factors (Fig. 5A-C, Table 5). Total aboveground plant biomass was negatively correlated $(P=0.045)$ to Factor 3 in the soil (adsorbed nutrients) and, accordingly, tended to 
Table 3 Rotated component matrix of soil parameters with the factor loadings for each variable on the factors after rotation. (a) Factor 1 indicates 'Total nutrients', Factor 2 'Salinity' and Factor 3 'Available nutrients'. (b) Factor 1 indicates 'Salinity', Factor 2 'Redox' and Factor 3 'Nutrients'. (c) Factor 1 indicates 'Salinity', Factor 2 'Nutrients' and Factor 3 'Redox'

\begin{tabular}{|c|c|c|c|}
\hline & Factor 1 & Factor 2 & Factor 3 \\
\hline \multicolumn{4}{|l|}{ (a) } \\
\hline Eigenvalue & 9.248 & 2.319 & 1.920 \\
\hline$\%$ of variance & 48.67 & 12.21 & 10.11 \\
\hline Moisture content $(\%)$ & .856 & .354 & \\
\hline Org. matter content $(\%)$ & .828 & .498 & \\
\hline $\mathrm{K}\left(\mathrm{mg} \mathrm{g}^{-1}\right)$ & .811 & -.299 & .102 \\
\hline Total $\mathrm{N}\left(\mathrm{mg} \mathrm{g}^{-1}\right)$ & .808 & .518 & \\
\hline Total P (mg g $\left.{ }^{-1}\right)$ & .794 & .394 & .236 \\
\hline Total K(mg g $\left.{ }^{-1}\right)$ & .759 & & \\
\hline $\operatorname{Mg}\left(\mathrm{mg} \mathrm{g}^{-1}\right)$ & 677 & .555 & \\
\hline $\mathrm{SO}_{4}\left(\mathrm{mg} \mathrm{g}^{-1}\right)$ & .596 & .379 & -.238 \\
\hline $\mathrm{PH}$ & -.330 & -.195 & \\
\hline $\mathrm{HCO}_{3}\left(\mathrm{mg} \mathrm{g}^{-1}\right)$ & & .892 & \\
\hline $\mathrm{Na}\left(\mathrm{mg} \mathrm{g}^{-1}\right)$ & .202 & .874 & \\
\hline $\mathrm{Cl}\left(\mathrm{mg} \mathrm{g}^{-1}\right)$ & .186 & .813 & .144 \\
\hline $\mathrm{EC}(\mu \mathrm{S})$ & .392 & .731 & \\
\hline $\mathrm{Ca}\left(\mathrm{mg} \mathrm{g}^{-1}\right)$ & .596 & .730 & \\
\hline $\mathrm{Fe}\left(\mathrm{mg} \mathrm{g}^{-1}\right)$ & .465 & 693 & \\
\hline $\mathrm{Al}\left(\mathrm{mg} \mathrm{g}^{-1}\right)$ & .320 & 693 & -.212 \\
\hline $\mathrm{NH}_{4}\left(\mathrm{mg} \mathrm{g}^{-1}\right)$ & & & .873 \\
\hline $\mathrm{PO}_{4}\left(\mathrm{mg} \mathrm{g}^{-1}\right)$ & .202 & -.148 & .766 \\
\hline $\begin{array}{l}\mathrm{NH}_{4}-\mathrm{KCl}\left(\mathrm{mg} \mathrm{g}^{-1}\right) \\
\text { (b) }\end{array}$ & -.134 & .230 & .628 \\
\hline Eigenvalue & 4.582 & 2.309 & 1.825 \\
\hline$\%$ of variance & 32.729 & 16.493 & 13.035 \\
\hline $\mathrm{EC}(\mu \mathrm{S})$ & .946 & & \\
\hline $\mathrm{Na}\left(\mathrm{mg} \mathrm{l}^{-1}\right)$ & .888 & & \\
\hline $\operatorname{Mg}\left(\mathrm{mg}^{-1}\right)$ & .767 & & .168 \\
\hline $\mathrm{Cl}\left(\mathrm{mg} \mathrm{l}^{-1}\right)$ & .740 & & \\
\hline $\mathrm{K}\left(\mathrm{mg} \mathrm{l}^{-1}\right)$ & .600 & .195 & .571 \\
\hline $\mathrm{Fe}\left(\mathrm{mg} \mathrm{l}^{-1}\right)$ & .471 & -.403 & \\
\hline $\mathrm{Al}\left(\mathrm{mg} \mathrm{l}^{-1}\right)$ & -.214 & .838 & \\
\hline $\mathrm{NO}_{3}\left(\mathrm{mg} \mathrm{l}^{-1}\right)$ & & .815 & \\
\hline $\mathrm{SO}_{4}\left(\mathrm{mg} \mathrm{l}^{-1}\right)$ & & .703 & -.422 \\
\hline $\mathrm{HCO}_{3}\left(\mathrm{mg} \mathrm{l}^{-1}\right)$ & .458 & -.623 & \\
\hline $\mathrm{PH}$ & & .535 & \\
\hline $\mathrm{NH}_{4}\left(\mathrm{mg} \mathrm{l}^{-1}\right)$ & .184 & & .796 \\
\hline $\mathrm{PO}_{4}\left(\mathrm{mg} \mathrm{l}^{-1}\right)$ & .259 & -.138 & .772 \\
\hline $\mathrm{Ca}\left(\mathrm{mg} \mathrm{l}^{-1}\right)$ & .237 & & -.557 \\
\hline
\end{tabular}

Table 3 continued

\begin{tabular}{|c|c|c|c|}
\hline & Factor 1 & Factor 2 & Factor 3 \\
\hline \multicolumn{4}{|l|}{ (c) } \\
\hline Eigenvalue & 4.192 & 3.306 & 1.472 \\
\hline$\%$ of variance & 32.248 & 25.431 & 11.324 \\
\hline $\mathrm{Na}\left(\mathrm{mg} \mathrm{l}^{-1}\right)$ & .960 & & \\
\hline $\operatorname{Mg}\left(\mathrm{mg} \mathrm{l}^{-1}\right)$ & .930 & & .170 \\
\hline $\mathrm{EC}(\mu \mathrm{S})$ & .908 & .196 & .178 \\
\hline $\mathrm{Ca}\left(\mathrm{mg} \mathrm{l}^{-1}\right)$ & -.660 & .213 & .408 \\
\hline $\mathrm{NO}_{3}\left(\mathrm{mg} \mathrm{l}^{-1}\right)$ & -.618 & & -.385 \\
\hline $\mathrm{Cl}\left(\mathrm{mg} \mathrm{l}^{-1}\right)$ & .615 & & \\
\hline $\mathrm{NH}_{4}\left(\mathrm{mg} \mathrm{l}^{-1}\right)$ & -.149 & .935 & \\
\hline $\mathrm{PH}$ & & -.888 & \\
\hline $\mathrm{HCO}_{3}\left(\mathrm{mg} \mathrm{l}^{-1}\right)$ & .394 & .754 & -.259 \\
\hline $\mathrm{PO}_{4}\left(\mathrm{mg} \mathrm{l}^{-1}\right)$ & & .733 & \\
\hline $\mathrm{K}\left(\mathrm{mg}^{-1}\right)$ & .157 & -.507 & .466 \\
\hline $\mathrm{SO}_{4}\left(\mathrm{mg} \mathrm{l}^{-1}\right)$ & .241 & -.318 & .760 \\
\hline $\mathrm{Fe}\left(\mathrm{mg} \mathrm{l}^{-1}\right)$ & & -.170 & -.633 \\
\hline
\end{tabular}

The eigenvalue gives the amount of variance in the observed variables accounted for by each factor. Percentage of variance gives the percent accounted for by each specific factor, relative to the total variance in all the variables

be negatively correlated $(P=0.061)$ to nutrients in the pore water (Factor 3). Total nutrients in the soil (Factor 1) increased with increasing aboveground biomass $(P=0.074)$. Lastly, redox potential in the pore water (Factor 2) showed a negative correlation with plant biomass $(P=0.038)$. No significant correlations were found between vegetation parameters and the PCA Factors for surface water.

Plant nutrient concentrations were not correlated to total or adsorbed nutrients in the soil, but positively to salinity (Factor 1$)$ in the pore water $(P=0.028$ for $\mathrm{N}$ and $P=0.013$ for $\mathrm{P})$. Total $\mathrm{N}, \mathrm{P}$ and $\mathrm{K}$ in the standing stock $\left(\mathrm{g} \mathrm{m}^{-2}\right)$ tended to have a negative correlation with Factor 1 in the soil (total nutrients) ( $P=0.060, P=0.055$ and $P=0.049$, respectively) and were negatively correlated to Factor 2 (redox) in the pore water $(P=0.021, \quad P=0.021$ and $P=0.034$, respectively).

Flooding duration and flooding frequency both did not have significant relations with nutrient concentrations in the soil (Fig. 5A). However, flooding duration was negatively correlated with Factor 1 (salinity) $(P=0.011)$ and Factor 2 (redox) $(P=0.011)$ (Fig. 5B) and positively with Factor 3 (nutrients) $(P=0.096)$ of the pore water (Fig. 5C). 
Table 4 Pearsons correlation coefficients between the Factors of soil, pore water and surface water

\begin{tabular}{|c|c|c|c|c|c|c|c|}
\hline & & \multicolumn{3}{|c|}{ Soil $(n=30)$} & \multicolumn{3}{|c|}{ Pore water $(n=29)$} \\
\hline & & $\begin{array}{l}\text { Factor } 1 \\
\text { (tot. nutr) }\end{array}$ & $\begin{array}{l}\text { Factor } 2 \\
\text { (salinity) }\end{array}$ & $\begin{array}{l}\text { Factor } 3 \\
\text { (av. nutr) }\end{array}$ & $\begin{array}{l}\text { Factor } 1 \\
\text { (salinity) }\end{array}$ & $\begin{array}{l}\text { Factor } 2 \\
\text { (redox) }\end{array}$ & $\begin{array}{l}\text { Factor } 3 \\
\text { (nutr) }\end{array}$ \\
\hline \multirow[t]{3}{*}{ Pore water } & Factor 1 (salinity) & $-0.240 *$ & $0.429 * * *$ & & & & \\
\hline & Factor 2 (redox) & $0.350 * * *$ & & & & & \\
\hline & Factor 3 (nutr.) & $-0.223 *$ & $-0.242 *$ & $0.597 * * *$ & & & \\
\hline \multirow[t]{3}{*}{ Surface water } & Factor 1 (salinity) & $-0.369 *$ & $0.806 * * *$ & & $0.729 * * *$ & & $0.464 * *$ \\
\hline & Factor 2 (nutr.) & & & & & $-0.486^{* *}$ & $-0.354 *$ \\
\hline & Factor 3 (redox) & & & & & & \\
\hline
\end{tabular}

*** $P<0.01, * * P<0.05, * P<0.1$

Fig. 5 (A-C) Correlations between vegetation/flooding parameters and factors defined in Table 3. Grey arrows are non-significant relations. Living, dead and total biomass in $\mathrm{g} \mathrm{m}^{-2}$; flooding duration (flo dur) in $\mathrm{h} \mathrm{day}^{-1}$; flooding frequency (flo freq) in number day $^{-1}$
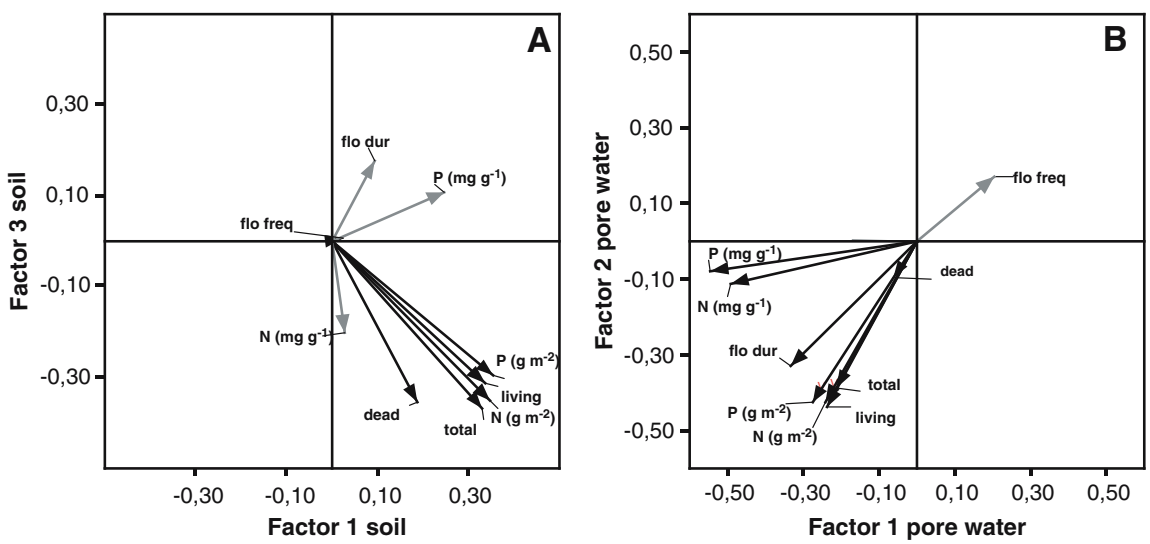

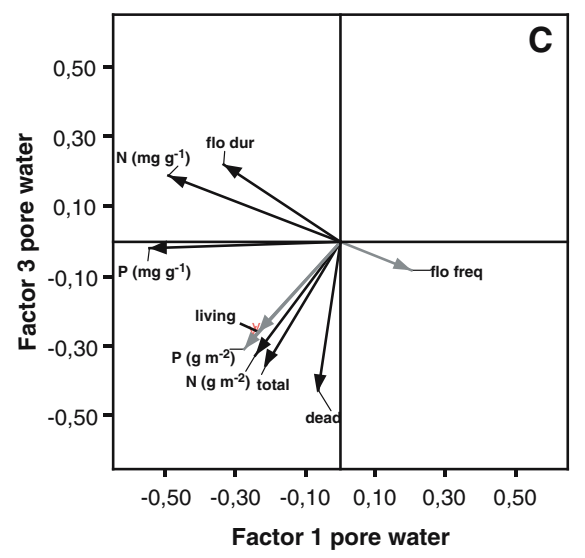

\section{Discussion}

Constructed versus natural littoral zones

The results enable some conclusions on the differences and similarities between constructed and natural littoral zones along shallow lakes. We hypothesized that due to the deposition of inorganic sand the constructed sites would be less organic, even after about $8-16$ years, and the vegetation would be less developed in a quantitative way. Therefore, we expected higher nutrient concentrations in the soil of the constructed site due to the lower uptake by the vegetation. The amount of organic matter, $\mathrm{TN}$ and $\mathrm{TP}$ in the soil were, however, as high in the constructed sites as in the natural sites. The accumulation rates in 
Table 5 Pearson's correlation coefficients between vegetation/flooding parameters and the factors (Fact) of the compartments soil, pore water and surface water

\begin{tabular}{|c|c|c|c|c|c|c|c|c|c|}
\hline & \multicolumn{3}{|c|}{ Soil $(n=30)$} & \multicolumn{3}{|c|}{ Pore water $(n=29)$} & \multicolumn{3}{|c|}{ Surface water $(n=11)$} \\
\hline & Fact 1 & Fact 2 & Fact 3 & Fact 1 & Fact 2 & Fact 3 & Fact 1 & Fact 2 & Fact 3 \\
\hline Total biomass $\left(\mathrm{g} \mathrm{m}^{-2}\right)$ & $0.330 *$ & -0.199 & $-0.369 * *$ & -0.211 & $-0.387 * *$ & $-0.352 *$ & -0.268 & -0.163 & 0.099 \\
\hline Dead biomass $\left(\mathrm{g} \mathrm{m}^{-2}\right)$ & 0.187 & -0.098 & $-0.356^{*}$ & -0.062 & $-0.099 * *$ & $-0.426^{* *}$ & -0.205 & -0.359 & 0.237 \\
\hline Living biomass $\left(\mathrm{g} \mathrm{m}^{-2}\right)$ & $0.336^{*}$ & -0.208 & $-0.313^{*}$ & -0.236 & -0.438 & -0.260 & -0.277 & -0.124 & 0.072 \\
\hline $\mathrm{N}$ in standing stock $\left(\mathrm{g} \mathrm{m}^{-2}\right)$ & $0.348^{*}$ & -0.236 & $-0.352 *$ & -0.241 & $-0.427 * *$ & $-0.325^{*}$ & -0.283 & -0.125 & -0.022 \\
\hline $\mathrm{P}$ in standing stock $\left(\mathrm{g} \mathrm{m}^{-2}\right)$ & $0.354 *$ & -0.139 & -0.298 & -0.276 & $-0.428 * *$ & -0.309 & -0.237 & -0.200 & 0.224 \\
\hline $\mathrm{K}$ in standing stock $\left(\mathrm{g} \mathrm{m}^{-2}\right)$ & $0.362 * *$ & -0.120 & -0.288 & -0.244 & $-0.396^{* *}$ & -0.268 & -0.226 & -0.280 & 0.187 \\
\hline $\mathrm{N}$ concentration $\left(\mathrm{mg} \mathrm{g}^{-1}\right)$ & 0.028 & -0.296 & -0.202 & $-0.490 * *$ & -0.112 & 0.186 & -0.402 & 0.107 & -0.553 \\
\hline $\mathrm{P}$ concentration $\left(\mathrm{mg} \mathrm{g}^{-1}\right)$ & 0.248 & 0.115 & 0.107 & $-0.545^{* *}$ & -0.080 & -0.020 & -0.701 & 0.036 & 0.423 \\
\hline $\mathrm{K}$ concentration $\left(\mathrm{mg} \mathrm{g}^{-1}\right)$ & 0.290 & 0.268 & 0.233 & -0.169 & 0.001 & 0.119 & 0.104 & -0.890 & 0.172 \\
\hline Flooding duration $\left(\mathrm{h}\right.$ day $^{-1}$ ) & 0.940 & -0.068 & 0.176 & $-0.333 * *$ & $-0.331 * *$ & $0.221 *$ & -0.317 & 0.103 & 0.062 \\
\hline Flooding frequency $\left(\right.$ day $\left.^{-1}\right)$ & 0.024 & 0.167 & 0.004 & 0.203 & 0.168 & -0.081 & -0.02 & 0.104 & 0.108 \\
\hline
\end{tabular}

** $P<0.05$ and $* P<0.1$

this study $\left(20 \mathrm{~g} \mathrm{~N}\right.$ and $3 \mathrm{~g} \mathrm{P} \mathrm{m}^{-2} \mathrm{y}^{-1}$ in the vegetated plots and $8 \mathrm{~g} \mathrm{~N}$ and $1.8 \mathrm{~g} \mathrm{P} \mathrm{m}^{-2} \mathrm{y}^{-1}$ in the unvegetated plots, both in the upper $10 \mathrm{~cm}$ of the soil) were comparable to the rates measured by Meuleman et al. (2003). They found accumulation rates of organic nutrients and sorption of inorganic nutrients of $21 \mathrm{~g} \mathrm{~N} \mathrm{~m}^{-2} \mathrm{y}^{-1}$ and $4.6 \mathrm{~g} \mathrm{P} \mathrm{m}^{-2} \mathrm{y}^{-1}$ in an infiltration wetland for wastewater treatment. This indicates that the relatively young natural areas studied function comparable to systems especially build for nutrient removal. Short pioneer species were prominent in the constructed sites (Table 1). Such vegetation is characterized by a relatively low standing biomass, but a high turnover rate, so that total productivity is high (Aerts et al., 1999), resulting in a rapid incorporation of organic matter in the soil.

We expected lower pore water nutrient concentrations in the natural sites, due to higher vegetation biomass and plant uptake. Our data showed this only for pore water ammonium. Nitrate and phosphate concentrations tended to be higher. Aboveground vegetation biomass and nutrient contents did not differ between the natural and constructed sites, hence there are no indications that lower nutrient concentrations in the pore water are determined by a smaller plant uptake in the constructed sites. Alternatively, the relatively high pore water nutrient contents in the constructed sites may be caused by a more open vegetation structure that facilitates the use by roosting waterfowl. The observation of bird droppings at these sites indicates a higher input of nutrients. It might be that bird droppings have added slightly to the accumulation of $\mathrm{N}$ and $\mathrm{P}$ in the constructed sites, but we have no data to quantify this effect.

Although vegetation biomass did not differ between the constructed and natural sites, vegetation structure was not the same. In the natural sites helophytes were dominant, whereas in the constructed sites helophytes were rarely occurring. The average aboveground biomass of tall helophytes in the littoral zone locations of the IJsselmeer area $\left(2,100 \mathrm{~g} \mathrm{~m}^{-2}\right)$ falls within the typical range of helophyte biomasses between 180 and $5,280 \mathrm{~g} \mathrm{~m}^{-2}$ (Gopal, 1990). It is assumed that the amount of nutrients present in the vegetation at the end of the growing season (August) represents the annual uptake of nutrients ((Meuleman et al., 2002; Van den Wyngaert et al., 2003). As a result of the largely different vegetation biomasses, a strong effect of vegetation type on nutrient storage capacity in aboveground plant mass was found; the annual $\mathrm{N}$ storage varied between 11 and $20 \mathrm{~g} \mathrm{~m}^{-2}$ and the $\mathrm{P}$ storage between 1.3 and $2.0 \mathrm{~g} \mathrm{~m}^{-2}$, for wetlands with different vegetation types, from the low-vegetation type to the monotypic helophyte stands, respectively. These amounts stored in the aboveground helophyte vegetation in August are high in comparison with other studies (Meuleman et al., 2002; Van den Wyngaert et al., 2003). 
$\mathrm{N}: \mathrm{P}$ ratios of plant biomass in the IJsselmeer area were relatively low, ranging between 6 and 10 for different vegetation types. Nutrient concentrations in the vegetation and their stoichiometric relationships may indicate the degree to which nutrients were limiting plant growth. In a review of 40 fertilisation studies in freshwater wetlands Koerselman \& Meuleman (1996) found that $\mathrm{N}: \mathrm{P}$ ratios less than 14 indicate $\mathrm{N}$ limitation. The $\mathrm{N}$ concentrations in the vegetation in this study were lower than $13 \mathrm{mg} \mathrm{g}^{-1}$, whereas $\mathrm{P}$ concentrations were higher than the 'critical' value of $0.7 \mathrm{mg} \mathrm{g}^{-1}$, which is also indicative of N-limited plant growth (Wassen et al., 1995).

Factors influencing nutrient retention

Although artificial littoral zones along lakes are usually created for other purposes than their ability to retain nutrients, they might be instrumental in reducing the nutrient concentrations in the surface water (Coveney et al., 2002; Meuleman et al., 2002; Verhoeven \& Meuleman, 1999). Water regime and vegetation type are important variables in determining the nutrient status in soil and pore water.

Water levels in the IJsselmeer area are maintained at a constant level within rather narrow limits, with targeted water levels about $20 \mathrm{~cm}$ higher in summer than in winter. Due to wind activity and sluice operations irregular, short-term flooding events occur in the littoral zone. Such inundations, accompanied by reductions of the redox potential will result in phosphate mobilisation and accumulation of ammonium, thus increasing nutrient concentrations (Patrick \& Mikkelsen, 1971). The negative correlation of flooding duration with pore water oxidised anion concentrations, indeed, confirmed the effects of flooding on redox potential. The very frequent, wind-driven wet-dry cycles in the shallow areas along the IJsselmeer probably prevent the occurrence of strongly anaerobic conditions in the inundated zone. We found only few significant correlations between flooding frequency and flooding duration, and available and total nutrient concentrations in littoral sediments. Ammonium availability was higher at sites with high flooding duration compared to sites with low flooding duration (data not shown). The accumulation of ammonium probably results from the absence of nitrification under anaerobic conditions (Ann et al.,
2000; Patrick \& Reddy, 1976; Patrick \& Mikkelsen, 1971).

We expected that vegetation biomass was an important factor determining the nutrient availability in soil and pore water. It is obvious that helophytes can store large amounts of nutrients, but does their presence in a littoral zone reduce the nutrient concentrations in the surface water? In our study sites no effect of vegetation type on nutrient concentrations in the surface water was found. We also found no clear correlations between vegetation biomass and nutrients in surface water. Effects of vegetation on nutrient concentrations in the surface water can be obscured by intensive mixing of vegetated and unvegetated zones. Indirect evidence supporting our expectations is provided by the significantly higher nutrient concentrations in the pore water in absence of vegetation. This was also reflected in the negative correlations between vegetation biomass and pore water nutrient concentrations. When nutrient concentrations in the soil decrease with vegetation biomass, it is assumed that diffusion also eventually will cause a decrease in surface water nutrient concentrations. Other research concerning water quality improvement by submerged water plants (Krolikowska, 1997; Coveney et al., 2002; Kufel \& Kufel, 2002) has shown that N and P concentrations in the surface water were significantly lower at sites covered with submerged plants than at sites devoid of plants. Emergent vegetation may reduce nutrient concentrations in surface water even more strongly, as has been demonstrated particularly in wetlands used for wastewater treatment (Tanner et al., 1999; Verhoeven \& Meuleman, 1999; Meuleman et al., 2002). Several studies have demonstrated that the retention time of water is very important for the amount of nutrients stored in the vegetation (Jing et al., 2002; Busnardo et al., 1992).

Apart from the effect of vegetation on pore water, vegetation biomass was also positively correlated with total nutrients in the soil in both constructed and natural areas. Nutrient accumulation rates in the constructed wetlands apparently were high enough to produce a soil nutrient status comparable to that of natural wetlands. The high organic matter accumulation of wetland soils is due to a high rate of primary production and a reduced rate of decomposition under anaerobic conditions (Reddy \& D'Angelo, 1994). The deposited material consists mainly of 
macrophytic plant material, containing large quantities of carbon, nitrogen and phosphorus. In addition, plant structure can act as a physical sediment trap (Cotton et al., 2006). These two factors may explain the increased organic matter content and nutrient contents of the soil in vegetated areas.

Vegetation can thus act as a nutrient sink by both uptake of nutrients and storage of nutrients in sequestering organic matter. Helophytes retain most of the nutrients for a long time, although a significant part of the nutrients may return to lake water and sediments at the end of the vegetation season (Krolikowska, 1997). Levine \& Schindler (1992) showed that $\mathrm{NH}_{4}^{+}$and $\mathrm{PO}_{4}^{3-}$ were mainly released in the surface water after mineralisation of organic matter. Only a small fraction was absorbed by sediments, immobilised by microbes or incorporated into minerals. Even as nutrients may return to the surface water at the end of the growing season, they are not available for phytoplankton growth.

Acknowledgements This research was conducted in the project 'Water level management and nutrients in shallow lakes', financed by the RIZA (Institute for Inland Water Management and Waste Water Treatment). The authors wish to thank Staatsbosbeheer, It Fryske Gea, Noorderstaete and RDIJ for allowing access to their field locations, and the colleagues of UU, Landscape Ecology and of RIZA for their useful help in both field and laboratory. Furthermore, we thank Dennis Whigham (SERC, USA) for critical discussion.

Open Access This article is distributed under the terms of the Creative Commons Attribution Noncommercial License which permits any noncommercial use, distribution, and reproduction in any medium, provided the original author(s) and source are credited.

\section{References}

Aerts, R., J. T. A. Verhoeven \& D. F. Wigham, 1999. Plantmediated controls on nutrient cycling in temperate fens and bogs. Ecology 80: 2170-2181.

Ann Y., K. R. Reddy \& J. J. Delfino, 2000. Influence of redox potential on phosphorus solubility in chemically amended wetland organic soils. Ecological Engineering 14: 169180.

Bray, R. H. \& L. T. Kurtz, 1945. Determination of total, organic, and available forms of phosphorus in soils. Soil Science 59: 39-45.

Bremner, J. M. \& C. S. Mulvaney, 1982. Salicylic acid-thiosulphate modification of Kjeldahl method to include nitrate and nitrite. In Page, A. C., R. H. Miller \& D. R. Keeney (eds). Methods of Soil Analysis. Part 2. American society of Agronomy, Madison, WI, USA, 621-622.
Busnardo, M. J., R. M. Gersberg, R. Langis, T. L. Sinicrope \& J. B. Zedler, 1992. Nitrogen and phosphorus removal by wetland mesocosms subjected to different hydroperiods. Ecological Engineering 1: 287-307.

Coops, H. \& S. H. Hosper, 2002. Water-level management as a tool for the restoration of shallow lakes in the Netherlands. Lake and Reservoir Management 18: 293-298.

Coops, H, S. Sollie \& R. Portielje, 2004. Lagere nutriëntengehalten in meren en plassen door natuurlijker peilbeheer? $\mathrm{H}_{2} \mathrm{O}$ : 25-27.

Cotton, J. A., G. Wharton, J. A. B. Bass, C. M. Heppell \& R. S. Wotton, 2006. The effects of seasonal changes to instream vegetation cover on patterns of flow and accumulation of sediment. Geomorphology 77: 320-334.

Coveney, M. F., D. L. Stites, E. F. Lowe, L. E. Battoe \& R. Conrow, 2002. Nutrient removal from eutrophic lake water by wetland filtration. Ecological Engineering 19: 141-159.

Gopal B., 1990. Biology and ecology. In Patten, B. C. (ed.), Wetlands and Shallow Continental Water Bodies, 91-239.

Gulati, R. D. \& E. Van Donk, 2002. Lakes in the Netherlands, their origin, eutrophication and restoration: state-of-theart review. Hydrobiologia 478: 73-106.

Houba, V. J. G., G. E. M. Van der Lee, I. Novozamsky \& I. Walinga, 1989. Soil and Plant Analysis: a Series of Syllabi. Part 5. Soil Analysis Procedures. Wageningen Agricultural University, The Netherlands.

James, W. F., E. P. Best \& J. W. Barko, 2004. Sediment resuspension and light attenuation in Peoria Lake: can macrophytes improve water quality in this shallow system? Hydrobiologia 515: 193-201.

Jing, S. R., Y. F. Lin, T. W. Wang \& D. Y. Lee, 2002. Microcosm wetlands for wastewater treatment with different hydraulic loading rates and macrophytes. Journal of Environmental Quality 31: 690-696.

Johnston, C. A., G. D. Bubenzer, G. B. Lee, F. W. Madison \& J. R. McHenry, 1984. Nutrient trapping by sediment deposition in a seasonally flooded lakeside wetland. Journal of Environmental Quality 13: 283-290.

Koerselman, W. \& A. F. M. Meuleman, 1996. The vegetation $\mathrm{N}: \mathrm{P}$ ratio: a new tool to detect the nature of nutrient limitation. Journal of Applied Ecology 33: 1441-1450.

Krolikowska, J., 1997. Eutrophication processes in a shallow, macrophyte-dominated lake-species differentiation, biomass and the distribution of submerged macrophytes in Lake Luknajno (Poland). Hydrobiologia 342/343: 411416.

Kufel, L. \& I. Kufel, 2002. Chara beds acting as nutrient sinks in shallow lakes-a review. Aquatic Botany 72: 249-260.

Lammens, E., 1999. Het voedselweb van IJsselmeer en Markermeer. Veldgegevens, hypothesen, modellen en scenario's. RIZA report 99.008. ISBN 903695228X (in Dutch).

Levine, S. N. \& D. W. Schindler, 1992. Modification of the N$P$ Ratio in Lakes by Insitu Processes. Limnology and Oceanography 37: 917-935.

Meuleman, A. F. M., J. P. Beekman \& J. T. A. Verhoeven, 2002. Nutrient retention and nutrient-use efficiency in Phragmites australis stands after waste water application. Wetlands 22: 712-721.

Meuleman, A. F. M., R. Van Logtestijn, G. B. J. Rijs \& J. T. A. Verhoeven, 2003. Water and mass budgets of a 
vertical-flow constructed wetland used for wastewater treatment. Ecological Engineering 20: 31-44.

Mitsch W. J. \& J. G. Gosselink, 2000. Wetland biogeochemistry. In Mitsch, W. J. \& J. G. Gosselink (eds), Wetlands, 3rd edn. Wiley, New York, 155-204.

Patrick, W. H. \& R. D. Delaune, 1977. Chemical and biological redox systems affecting nutrient availability in the coastal wetlands. Geoscience and Man 18: 131-137.

Patrick, W. H. \& D. S. Mikkelsen, 1971. Plant nutrient behaviour in flooded soils. Advances in Agronomy 1971: 187-212.

Patrick, W. H. \& K. R. Reddy, 1976. Nitrification-denitrification reactions in flooded soils and water bottoms: dependence on oxygen supply and ammonium diffusion. Journal of Environmental Quality 5: 469-472.

Reddy K. R. \& E. M. D’Angelo, 1994. Soil processes regulating water quality in wetlands. In Mitsch, W. J. (ed.), Global Wetlands: Old World and New. Elsevier, Amsterdam, 309-324.

Scheffer, M., 2001. Alternative attractors of shallow lakes. The Scientific World 1: 254-263.

Smith, V. H., 2003. Eutrophication of freshwater and coastal marine ecosystems-a global problem. Environmental Science and Pollution Research 10: 126-139.
Søndergaard, M., J. P. Jensen \& E. Jeppesen, 2003. Role of sediment and internal loading of phosphorus in shallow lakes. Hydrobiologia 506(1-3): 135-145.

Tanner, C. C., J. D’Eugenio, G. B. McBride, J. P. S. Sukias \& K. Thompson, 1999. Effect of water level fluctuation on nitrogen removal from constructed wetland mesocosms. Ecological Engineering 12: 67-92.

Van den Wyngaert, I. J. J., L. D. Wienk, S. Sollie, R. Bobbink \& J. T. A. Verhoeven, 2003. Long-term effects of yearly grazing by moulting Greylag geese (Anser anser) on reed (Phragmites australis) growth and nutrient dynamics. Aquatic Botany 75: 229-248.

Verhoeven, J. T. A. \& A. F. M. Meuleman, 1999. Wetlands for wastewater treatment: opportunities and limitations. Ecological Engineering 12: 5-12.

Wassen, M. J., H. G. M. Olde Venterink \& E. O. A. M. Deswart, 1995. Nutrient concentrations in mire vegetation as a measure of nutrient limitation in mire ecosystems. Journal of Vegetation Science 6: 5-16.

Yang, H., Z. Shen, S. Zhu \& W. Wang, 2007. Vertical and temporal distribution of nitrogen and phosphorus and relationship with their influencing factors in aquatic-terrestrial ecotone: a case study in Taihu Lake, China. Journal of Environmental Sciences 19: 689-695. 